УДК $340.01 ; 340.134$

DOI https://doi.org/10.32837/pyuv.v0i2(27).180

\author{
А. А.Шелих \\ студент юридичного факультету \\ Київського національного університету ілені Тараса Шевченка
}

\title{
ПРАВОСВІДОМІСТЬ: ДОКТРИНАЛЬНІ ПІДХОДИ ДО РОЗУМІННЯ
}

На сучасному етапі Україна перебуває в умовах переходу від пострадянських моделей управління суспільством та механізму регулювання суспільних відносин до становлення правової соціальної держави. Відповідні зміни в різноманітних сфеpax суспільного життя зумовлюють важливість готовності суспільства до сприйняти таких змін і можуть навіть стати їх генератором. Ключову роль у цьому процесі відіграє правосвідомість, оскільки вона відображає усвідомлення людиною необхідності вчиняти правомірну поведінку, а також розуміння ï значення у забезпеченні суспільного розвитку. У зв'язку з цим для суспільного розвитку стає необхідною наявність високого рівня правосвідомості не лише народу, а і політичної еліти, що забезпечить, з одного боку, умови для прийняття ефективних законів, а $з$ іншого - переконаність у необхідності їх виконання. Проте в сучасному українському суспільстві відбуваються зовсім протилежні процеси, пов'язані 3 прийняттям недопрацьованих та необгрунтованих законів, які здебільшого не мають чіткого механізму реалізації, спричиняючи недовіру населення до цих законів і небажання їх виконувати. Відповідно, у суспільстві дедалі більше наростає проблема поширення різноманітних форм деформації правосвідомості. У зв'язку з цим значної наукової актуалізації набуває проблема дослідження і переосмислення цінності категорії «правосвідомість», вироблення на доктринальному рівні механізмів підвищення іï ролі як серед населення, так і серед представників влади. Актуальність дослідження правосвідомості пов'язана із ключовим значенням правосвідомості для правопорядку та розбудови правової держави. Глибше пізнання сутності цієї категорії забезпечить обгрунтування ефективних способів забезпечення правопорядку, які є найменш затратними, а також дозволить розробити найдоцільніший шлях імплементації цінностей, притаманних правовій державі, в українську реальність.

Ця проблема досліджувалася в роботах таких вчених, як С.С. Алексєєв, О.Л. Богінич, В.В. Дудченко, Т.З. Гарасимів, С.Д. Гусарєв, М.I. Козюбра, А.М. Колодій, М.М. Косович, В.В. Лемак, А.В. Малько, Р.О. Наливайко, Н.М. Оніщенко, С.Ф. Хопта, О.В. Петришин, А.С. Піголкін, П.М. Рабінович, О.Ф. Скакун, Т.І. Тарахонич, М.В. Цвік, Ю.С. Шемшученко. Цими науковцями було зроблено значний доробок у пізнанні сутнос- ті категорії правосвідомості. Однак незважаючи на обгрунтовані ними ідеї, все ж залишаються питання, що потребують більш детального дослідження та складають мету цієї публікації. Вона полягає у дослідженні доктринальних підходів до розуміння категорії «правосвідомість» і обгрунтування власного розуміння цієї категорії.

Важливою, однак не достатньо дослідженою проблемою сучасної юридичної науки є деградація суспільства і поширення різних видів деформації правосвідомості. На нашу думку, це насамперед пов'язано з недостатньою правовою освітою населення, а також відсутністю практичного застосування численних доктринальних досліджень категорії «правосвідомість». Проте варто зазначити, що правосвідомість має складний багатоаспектний характер і різні рівні прояву, що підтверджує необхідність подальшого вивчення і поглиблення знань про це явище. На нашу думку, переосмислення категорії «правосвідомість» потребує дослідження різних підходів до ії розуміння.

Перш ніж розпочати аналіз обраної проблематики, на нашу думку, необхідно визначити сутність поняття «доктринальний підхід», що $€$ ключовим у нашому дослідженні. Це поняття $є$ складником методології, філософська основа якої зумовлює необхідність аналізу цієї категорії саме з філософської точки зору. «Всесвітня енциклопедія філософії» розкриває категорію «підхід» як комплекс парадигматичних, синтегматичних і прагматичних структур та механізмів у пізнанні або практиці, який характеризує конкуруючі між собою (або ті, що історично змінюють одна одну) стратегії і програми у філософії, науці, політиці або в організації життя та діяльності людей $[1$, c. 1311]. Виходячи з аналізованого визначення поняття "підхід», зокрема як частини методології науки, можливо стверджувати, що «підхід» - це комплекс механізмів, за допомогою яких здійснюється пізнання, який характеризує стратегії та програми його здійснення. Також варто звернути увагу й на іншу важливу категорію - доктрину. Доктрина є системостворюючим елементом, який забезпечує методологічні засади дослідження [2, с. 249]. Термін «доктрина» походить від лат. doctrina - вчення, наука, знання і означає сукупність поглядів, переконань, тверджень, які мають систематизований, цілісний характер і стосуються певної сфери суспільного життя [3, с. 3]. Отже, доктрина складає основу методології дослідження 
правових систем, що підкреслює не тільки філософське, а й наукове значення методології. Природа доктрини виявляється також у тому, що це не проста сукупність, а цілісна система вчень, знань, поглядів і переконань, що надає можливість виокремити головне призначення і мету доктрини - забезпечення узгодженості, наступності і взаємозв'язку різних вчень і поглядів для цілісного пізнання тих чи інших явищ. Фактично доктрина це і є сама наука як явище, завдяки чому можливо зазначити, що поняття «доктринальний підхід» можна охарактеризувати як наукове. Сама наука - це передусім творчий процес, тому в імперативній формі неможливо нав'язати вченому той чи інший підхід. Вибір підходу безпосередньо залежить від світогляду і ціннісних орієнтирів самого дослідника. У зв'язку з цим у юридичній науці обгрунтовуються різні підходи до розуміння одного і того ж явища. Це стосується і категорії «правосвідомість», яка була досліджена різними вченими і у різний час.

Вчені-теоретики внесли значний доробок у осмислення поняття правосвідомості. Однією 3 фундаментальних праць стала робота С.С. Алексєєва. Вчений розуміє правосвідомість як суб'єктивну реакцію людини на право. Це пов'язано з тим, що право як соціальне явище викликає певну реакцію людей, яка може бути або позитивною (людина розуміє сутність права і його необхідність), або ж негативною (людина вважає право непотрібним). Окрім того, вчений зазначає, що право завжди невіддільне і тісно пов'язане 3 правосвідомістю, оскільки регулює поведінку людей, наділених волею і свідомістю [4, с. 142].

С.С. Алексєєв як один 3 фундаторів теорії права характеризує правосвідомість як явище суб'єктивне, яке викликає особисту позитивну чи негативну реакцію людей на право. Вчений справедливо наголошує на нерозривності права $з$ правосвідомістю. Проте хотілося б зазначити, що, на нашу думку, поняття, яке обгрунтовує С.С. Алексєєв, є дещо звуженим і неповним, оскільки правосвідомість це не лише реакція людини на право, яка є результатом уявлень про право та емоцій, це ще й сукупність знань про право, що формуються під впливом законодавства, 3МI, правових настанов тощо. До того ж реакція - це поняття короткочасне, натомість правосвідомість - це частина свідомості людини, яка забезпечує сприйняття правових явищ на постійній основі, тобто є сталим усвідомленням цінності права. Підхід, обгрунтований С.С. Алексєєвим, все ж розкриває фундаментальну сутність правосвідомості як явища психологічного, пов'язаного насамперед з реакцією людини на право.

Важливими для осмислення правосвідомості стали ідеї I.Є. Фарбера, який, подолавши марксистську заідеологізованість, обгрунтував цю категорію як соціальне явище, що пов'язує об’єктивні та суб'єктивні фактори свідомості та правової реальності [5, с. 4]. У своїй праці науковець досліджує такі ключові елементи правосвідомості, як правова ідеологія і правова психологія, а також зосереджує увагу на ролі правосвідомості у превенції правопорушень і забезпеченні загального правопорядку.

Загальнотеоретична наука XXI ст. не виробила єдиного підходу до розуміння правосвідомості. Так, на думку Н.М. Пархоменко, правосвідомість - це сукупність ідей, уявлень, почуттів, які відображають ставлення суспільства до права, його структури, механізму правового регулювання суспільних відносин. 3 іншого боку, правосвідомість можна розглядати як спосіб впливу права через свідомість окремих індивідів та закріплення навичок їх правової позитивної поведінки. Об’єктивним є взаємозв'язок права і правосвідомості [6, с. 553-555]. Це визначення широко розкриває ставлення особи через правосвідомість до різних елементів правової системи, тобто наголошується на тому, що правосвідомість - це не тільки ставлення до права, а й до інших елементів правової системи. Також особливої уваги заслуговує те, що H.M. Пархоменко розглядає правосвідомість як спосіб впливу права на індивідів через їх свідомість, що підкреслює значення правосвідомості в механізмі правового регулювання. Вчена справедливо наголошує на закріпленні навичок правової поведінки за допомогою правосвідомості, оскільки вона є частиною людської свідомості, якою індивід керується під час вчинення тих чи інших дій. Н.М. Пархоменко широко і грунтовно підходить до розуміння такого складного і багатоаспектного явища, як правосвідомість, але хотілося б зазначити, що вчена у своєму визначенні не торкається такого елементу правосвідомості, як юридичне знання, що також є важливим складником правосвідомості, зокрема, юридичні знання є частиною професійної правосвідомості, яка не може грунтуватися винятково на емоціях і почуттях.

Наступний підхід, який ми розглянемо в межах нашого дослідження, був обгрунтований науковцями В.М. Субботіним, О.В. Філоновим, Л.М. Князьковою, І.Я. Тодоровим. Поняття «правосвідомість» розглядається як явище ідеальне, яке не можна безпосередньо спостерігати. Воно являє собою сферу чи зону свідомості, що відбиває правову дійсність у формі юридичних знань та оцінного ставлення до права і практики його реалізації, соціально-правових установок і ціннісних орієнтацій, що регулюють поведінку людей у юридично значущих ситуаціях [7, с. 297]. Цей підхід є досить широким і найповніше розкриває сутність правосвідомості, оскільки охоплює такі її складники, як юридичні знання і оціночне ставлення до правової дійсності. Окрім цього, автори звер- 
тають увагу на регулятивний складник правосвідомості, оскільки вона за допомогою установок та ціннісних орієнтирів, які містяться у свідомості людини, забезпечує регулювання поведінки індивіда у юридично значущих ситуаціях, наприклад, під час переходу через пішохідний перехід (особа може перейти на червоне світло, а може на зелене) або під час виконання зобов'язання по перевезенню товару (особа може виконати умови договору або ж їх порушити).

Правосвідомість - це сукупність правових уявлень, поглядів, ідей, почуттів та емоцій, які виражають оціночне психологічне ставлення людей до права, діяльності, пов'язаної з ним, та юридично значущих явищ громадського життя (до чинного законодавства, юридичної практики, прав і свобод людини і громадянина). Таке визначення обгрунтовує професор Р.А. Ромашов [8, с. 191]. Вчений справедливо зазначає, що правосвідомість - це не тільки ставлення до права, а й до інших елементів громадського життя, якими можуть бути і органи держави, і законодавство, і механізм правового регулювання, тобто будь-який елемент правової системи суспільства. Водночас автор зупиняється на тому, що правосвідомість це сукупність ідей, теорій, почуттів і принципів, відводячи менше уваги юридичним знанням, які є також невіддільним складником правосвідомості.

Дуже оригінально до визначення правосвідомості підійшов А.I. Корольов. Вчений розуміє це явище як фільтр, через який пропускаються фактори впливу на право. Правосвідомість являє собою сукупність почуттів, настанов, уявлень, поглядів тощо, в яких відображено відношення до діючого права і до створюваних юридичних норм [9, с. 337]. На нашу думку, є дуже вдалою аналогія правосвідомості з певним фільтром, за допомогою якого ми сприймаємо правову дійсність, оскільки правосвідомість складають юридичні знання і правові відчуття й емоції, досвід, через призму яких і відображається правова дійсність у нашій свідомості. Правомірним буде зазначити, що професор А.I. Корольов у своєму визначенні акцентує увагу саме на діючому і створюваному праві, з чим ми можемо не погодитися, оскільки правова свідомість передбачає оцінку права діючого, бажаного, минулого, яке також має суттєве значення для формування правосвідомості і здійснює вплив на сучасну правову систему.

А.С. Піголкін визначає правосвідомість як сукупність певних поглядів, переконань, ідей, почуттів, що відображають правові потреби, інтереси особистісного i суспільного розвитку. Правосвідомість охоплює знання про нормативно-правові системи минулих епох, оцінку чинного законодавства, уявлення про його можливі чи необхідні вдосконалення, різноманітні правові установки, зв'язані з тими чи іншими правовими звичаями і традиціями [10, с. 94-95]. Як бачимо, А.С. Піголкін, на відміну від А.І. Корольова, розглядає правосвідомість у трьох вимірах, а саме ставлення до права минулих епох, чинного права і права майбутнього, а також вказує на значення правових звичаїв і традицій, що разом з іншими факторами здійснюють суттєвий вплив на формування правової свідомості. Неможливо не погодитися з професором А.С. Піголкіним щодо того, що правосвідомість відображає правові потреби та інтереси особистісного і суспільного розвитку, оскільки правосвідомість - це усвідомлення індивідом потреби та його зацікавленості у особистісному та суспільному розвитку, відповідно, такий індивід буде діяти правомірно, а якщо особа не усвідомлює цього, вона буде вчиняти неправомірно. Виходячи з вищезазначеного, можемо зробити висновок, що такий підхід розкриває об'єктивну (потреба) та суб'єктивну (інтерес) зумовленість правової поведінки, яка реалізується під впливом правосвідомості як усвідомлення необхідності здійснювати саме таку поведінку.

Інший підхід до розуміння правосвідомості розкриває професор А.М. Колодій. Вчений вважає, що правосвідомість - це специфічна форма суспільної свідомості, система відображення правової дійсності у поглядах, теоріях, концепціях, почуттях, уявленнях людей про право, його місце і роль щодо забезпечення свободи особи та інших загальнолюдських цінностей $[11$, с. 176]. Таке визначення розширює наше уявлення про правосвідомість як засіб пізнання права, його місця і ролі у забезпеченні свободи особи та інших загальнолюдських цінностей. Отже, можемо зробити висновок щодо важливості пізнавальної функції правосвідомості. Ми цілком погоджуємося, що це є однією 3 фундаментальних функцій правосвідомості, до яких ми ще можемо віднести регулятивну.

С.Ф. Хопта у своєму дисертаційному дослідженні наводить лаконічне і влучне визначення правосвідомості. Він зазначає, що правосвідомість за своєю природою - це усвідомлення права [12, с. 66]. Це абсолютно точне визначення, яке розкриває головну сутність правосвідомості як складника свідомості людини, що забезпечує пізнання права.

Досить широке визначення обгрунтував професор Ф.Ш. Ямбушев. Він вважає, що правосвідомість $\mathrm{E}$ специфічною нормативною формою суспільної свідомості, яка відображає правову дійсність, впливає на неї і формує певні уявлення і судження про внутрішньодержавні і міжнародні правові явища і відображається на основі правових традицій і соціального досвіду у системі ідей, поглядів, доктрин, а також психічно усвідомленого і неусвідомленого ставлення до них, правовій поведінці суб'єктів, діяльності владних органів за допомогою почуттів, емоцій, мотивів, установок та волі як процесу саморегуляції поведінкового 
акту у досягненні певної соціально значущої мети у сфері дії права [13, с. 18]. Це визначення охоплює практично всі аспекти цього явища, зокрема, психологічний, ідеологічний і поведінковий. Важливим є те, що Ф.Ш. Ямбушев звертає увагу на діяльність органів влади як одну з форм відображення правової свідомості, що допомагає нам ще більше порівняно з попередніми визначеннями розширити уявлення про правосвідомість, зокрема, щодо необхідності високого рівня правосвідомості не тільки у звичайних людей, а і в тих осіб, що здійснюють управління державою, що забез печить прийняття чітких ефективних законів, які будуть виконуватися населенням, оскільки воно усвідомлюватиме реальну необхідність їх дотримання і буде переконане в їх доцільності. Особливе значення результат дослідження Ф.М. Ямбушева має для становлення і розвитку України як правової і соціальної держави. До того ж вчений звертає увагу і на те, що правосвідомість - це засіб саморегуляції поведінкового акту у процесі досягнення певної соціально значущої мети у сфері дії права, тобто розкривається значення правосвідомості як елемента механізму правового регулювання суспільства, ï регулятивна функція. Узагальнюючи, справедливо зазначити, що Ф.Ш. Ямбушев у своєму підході до визначення поняття «правосвідомість» максимально повно розкрив сутність цього явища. Це визначення не тільки узагальнено характеризує правосвідомість як правову категорію, але і торкається ознак таких видів правосвідомості, як побутова, професійна і наукова. Хоча варто зазначити, що все ж у цьому підході недостатньо розкрито значення юридичних знань, які є важливими елементами правосвідомості.

Здійснюючи аналіз вищенаведених доктринальних підходів, можемо зробити їх класифікацію за певними критеріями, як-от: за ступенем абстрактності; за місцем психологічного елемента; за місцем юридичних знань; за функцією. Значення класифікації полягає у можливості виокремлення загальних та особливих ознак певного явища, визначення його місця серед аналогічних явищ загалом. Дозволяє глибше пізнати сутність явища, виокремити його позитивні і негативні риси. За ступенем абстрактності вищенаведені визначення можна поділити на ті, що характеризуються значним ступенем абстрактності (розуміння С.Ф. Хопти), і ті, що мають більш конкретний характер (підхід А.С. Піголкіна). За місием психологічного елемента у розумінні правосвідомості можна виокремити ті, в яких емоції і почуття $€$ ключовими елементами правосвідомості (згідно з С.С. Алексєєвим правосвідомість це реакція на право), і ті, де емоції і почуття є лише одним з елементів такого складного і багатоаспектного явища, як правосвідомість (розуміння А.М Колодія, за яким поряд з психологічним елементом виокремлено ідеологічний елемент теорії і концепціі). Також можна здійснити класифікацію за місиел юридичних знань у структурі правосвідомості та виокремити ті, у яких юридичні знання не відіграють значної ролі (підхід Р.А. Ромашова, де не згадується про роль юридичних знань), і ті, у яких юридичні знання є рівноцінним елементом правосвідомості (розуміння В.М. Субботіна, О.В. Філонова, Л.М. Князькової, І.Я. Тодорова, за яким однією із форм прояву правосвідомості є юридичні знання). За функиією, яка розкривається у визначенні поняття правосвідомості, можливо виокремити підходи, які акцентують увагу на пізнавальній функції (А.М. Колодій), і ті, що зосереджуються на регулятивній функції (Ф.Ш. Ямбушев).

Проаналізувавши усі вищенаведені доктринальні підходи до розуміння досліджуваного поняття, насамперед варто зазначити, що правосвідомість - це не просто сукупність різних елементів, це складний механізм, що є засобом сприйняття правової дійсності, тобто це певний фільтр, через який просочується інформація про право, і залежно від «матеріалу», з якого він зроблений, інформація відображається у свідомості людини тим чи іншим чином (повага до права або правовий нігілізм). Під «матеріалом» ми маємо на увазі правові знання, різні емоції, уявлення, ідеї, переконання. Залежно від наявності чи відсутності правових знань, характеру емоцій i переконань (позитивних або негативних), пов'язаних з правом, правова дійсність по-різному буде відображатися у свідомості людини, а це, відповідно, сформує різне ставлення до права і спричинить різні поведінкові форми у юридично значущих ситуаціях. Ми використовуємо термін «правові знання» тому, що термін «юридичні знання» є вужчим поняттям і здебільшого притаманний для юристів-практиків і юристів-науковців, натомість правові знання, на нашу думку, є ширшим поняттям і стосуються усіх знань, набутих у сфері права чи пов'язаних з правом, тобто є притаманними не тільки для науковців і практиків, а й для побутової правосвідомості пересічних громадян. Отже, у нашому розумінні правосвідомість - це певний фільтр, через який забезпечується сприйняття правової дійсності, формується оціночне ставлення до неї і який уособлюється у формі правових знань, почуттів, емоцій, уявлень і переконань. Виходячи із запропонованого визначення, можемо виокремити ряд ознак категорії «правосвідомість»: 1) це засіб сприйняття правової дійсності; 2) забезпечення формування оцінного ставлення до правової дійсності; 3) має певну форму уособлення; 4) є складним явищем, оскільки складається із сукупності правових знань, почуттів, емоцій і переконань; 5) здійснює регулятивну і пізнавальну функцію; 
6) поширюється на всі без винятку елементи правової дійсності.

$\mathrm{y}$ загальному висновку справедливо зазначити, що правосвідомість це складна і багатоаспектна категорія, пов'язана з психологічною та ідеологічною природою, у зв'язку з цим в юридичній науці $є$ багато різних підходів до розуміння цього поняття. В усіх цих підходах досить точно і грунтовно здійснюється характеристика різних аспектів правосвідомості, а які саме аспекти розкриваються у тому чи іншому визначенні залежить від світогляду вченого і його ціннісних орієнтирів. У власному підході до розуміння поняття «правосвідомість» ми намагалися якомога ширше відобразити цю категорію за допомогою значного ступеню абстракції, а також обгрунтувати сутність цього явища. Правосвідомість має фундаментальне значення для функціонування механізму правового регулювання і для розвитку правової держави загалом. Це зумовлює необхідність детального вивчення цієї категорії з подальшим упровадженням у життя результатів доктринальних досліджень для забезпечення високого рівня правосвідомості населення та представників державної влади і вирішення проблеми запобігання деформації правосвідомості у суспільстві.

\section{Jimepamypa}

1. Всемирная энциклопедия философии. Москва : АCT, Минск : Харвет, 2001. 794 с.

2. Полянський Є.Ю. Поняття доктрини, iї місце та значення в кримінальному праві США. Вчені записки Таврійського національного університету ім. В.I. Вернадського. Серія «Юридичні науки». Том 26 (65). 2013. № 2-1 (Ч.»). С. 249-255.

3. А.С. Романюк. Політичні доктрини XX століття навчальний посібник. Львів : Тріада плюс, 2009. 216 с.

4. Теория государства и права / Алексеева С.С., Архипова С.И. и др. Москва : Юрид. лит., 2005. 496 с.

5. Фарбер И.Е. Правосознание как форма общественного сознания. Москва : Госюриздат, 1963. 206 с.

6. Теорія держави і права: Академічний курс : підручник. За ред. О.В. Зайчука, Н.М. Оніщенко та ін. Київ : Юрінком Інтер, 2008. 688 с.

7. Теорія держави і права : навч. посіб. / В.М. Субботін, О.В. Філонов, Л.М. Князькова, І.Я. Тодоров. Київ : Знання, 2005. 327 с.

8. Теорія держави і права : навчальний посібник / За заг. ред. проф. Р.А Ромашова та д.ю.н. Н.М. Пархоменко. Київ : КНТ, 2007. 216 c.

9. Теория государства и права / Под ред. А.И. Королева, Ю.К. Толстого, Л.С. Явича. Ленинград : Изд-во Ленинград. ун-та, 1987. 495 с.

10. Теория государства и права / Под ред. Пиголкина А.С. Москва : Городец, 2003. $544 \mathrm{c}$.

11. Теорія держави і права : навч. посіб / За заг. ред. С. Л. Лисенкова. Київ : Юрінком Інтер, 2002. 368 с.

12. Хопта С.Ф. Теоретико-правові аспекти професійної правосвідомості судді та її роль в ухваленні судових рішень [Текст] : автореф. дис. ... канд. юрид. наук. Київ : Нац. ун-т імені Тараса Шевченка. Київ, 2018.18 с.

13. Ямбушев Ф.Ш. Правовое сознание в механизме правового регулирования общественных отношений : дис. ... кандата юрид. наук : Н. Новгород, 2002. 205 с.

\section{Анотація}

Шелих А. А. Правосвідомість: доктринальні підходи до розуміння. - Стаття.

У статті обгрунтована теоретична та практична значимість правосвідомості як засобу усвідомлення суб'єктами необхідності правомірної поведінки, що забезпечує суспільний розвиток. Наголошено на проблемі поширення різноманітних форм деформації правосвідомості. Обг'рунтовується необхідність переосмислення цінності категорії «правосвідомість», вироблення механізмів підвищення її ролі як серед населення, так і серед представників влади. Актуальність дослідження правосвідомості пов'язана також із її ключовим значенням для правопорядку та розбудови держави.

Правосвідомість досліджена як складне багатоаспектне явище, що має різні рівні прояву та потребує не лише вивчення, а й переосмислення. У статті проаналізовано та узагальнено наявні доктринальні уявлення про правосвідомість, визначено їх позитивні та негативні риси. Констатовано факт, що загальнотеоретична наука XXI ст. не виробила єдиного підходу до розуміння правосвідомості. Наявні визначення класифіковані через ставлення суб'єктів до права та елементів правової системи, вплив права на індивідів, закріплення навичок правової поведінки за допомогою відбиття правової дійсності, юридичні знання та оціночне ставлення до практики, соціально-правові установки та ціннісні орієнтації суб'єктів через пізнання права, його місце і роль у забезпеченні свободи особи та загальнолюдських цінностей.

Обгрунтоване авторське визначення правосвідомості як фільтру, через який забезпечується сприйняття правової дійсності, формується оціночне ставлення до неї і який уособлюється у формі правових знань, почуттів, емоцій, уявлень і переконань. Ознаками правосвідомості визначено: забезпечення сприйняття правової дійсності; формування оціночного ставлення до неї; повна форма уособлення; складається із сукупності правових знань, почуттів, емоцій і переконань; виконує регулятивну і пізнавальну функцію; поширюється на всі без винятку елементи правової дійсності.

Ключові слова: право, правова система, правосвідомість, пізнання, правові знання, правові емоції та переконання.

\section{Summary}

Shelykh A. A. Right: doctrinal approaches to understanding. - Article.

The article substantiates the theoretical and practical importance of legal awareness as a means of understanding the need for legitimate behavior to ensure social development. The problem of the spread of various forms of deformation of consciousness was emphasized. The necessity of rethinking the value of the category "justice", elaborating mechanisms to increase its role among the population and among the authorities is substantiated. The relevance of the study of justice is also linked to its key importance for the rule of law and state-building.

Legal consciousness has been investigated as a complex multidimensional phenomenon that has different levels of manifestation and needs not only study but also rethinking. The article analyzes and summarizes the existing doctrinal ideas of consciousness, identifies their positive and negative features. It is stated that the general theoretical science of the 21st century. did not develop a unified approach to understanding justice. Existing definitions are classified by the subject's attitude to law and elements of the legal system, the impact of the 
right on individuals, the consolidation of legal behavior skills through assistance, reflection of legal reality, legal knowledge and appraisal of practice, social and legal attitudes and values of subjects, through knowledge of the right of his place and role in ensuring the freedom of the individual and universal values.

The author's substantiated definition of justice as a filter through which the perception of legal reality is secured, an appraisal attitude to it is formed and which is embodied in the form of legal knowledge, feelings, emotions, representations and beliefs. As signs of justice defined ensuring the perception of legal reality, the formation of evaluative attitude to it, the complete form of embodiment, consists of a set of legal knowledge, feelings, emotions and beliefs, performs regulatory and cognitive function, applies to all without exception elements of legal reality.

Key words: law, legal system, justice, cognition, legal system, legal consciousness, cognition, legal knowledge, legal emotions, and beliefs. 